\title{
Sediment transport on the shelf margin of the Grand Banks of Newfoundland
}

\author{
J. V. Barrie* \\ C-CORE and Department of Earth Sciences, Memorial University of Newfoundland, \\ St.John's, Newfoundland AlB 3X5, Canada
}

and

M. B. Collins

Department of Oceanography, The University, Southampton S09 5NH, United Kingdom

Date Received January 3, 1989

Date Accepted August 3, 1989

\begin{abstract}
A thin cover of sand and gravel, formed during the early Holocene transgression, covers the northeastern Grand Banks of Newfoundland in water depths of between 70 and $130 \mathrm{~m}$. The sediments are presently being reworked but only during the winter months of higher wave activity. Sediment threshold under waves in $70 \mathrm{~m}$ water depth is exceeded over $30 \%$ of the time during the months of November to March. Net sediment transport is towards the south-southeast, parallel to the bathymetric contours. Currents required to generate the larger bedforms are known to occur only infrequently. Hence, combined wave and steady flow, often in the same direction, are the probable generating mechanism for the bedforms.
\end{abstract}

Une pellicule de sable et de gravier, formée lors de la transgression du début de l'Holocène, recouvre le nord-est du Grand Banc de Terre-Neuve à une bathymétrie de 70 à $130 \mathrm{~m}$. Les sédiments sont actuellement remaniés quoique seulement durănt les mois d'hiver alors que l'action des vagues est plus intense. Le seuil de prise en charge du sédiment par les vagues à une profondeur de $70 \mathrm{~m}$, est dépassé pendant plus de $30 \%$ du temps durant les mois allant de novembre à mars. Le transit sédimentaire net s'effectue vers le sud-sud-est, parallèlement aux lignes d'isobathymétrie. Les courants requis pour engendrer les formes de litage plus imposantes ne surviennent qu'infréquemment. Par conséquent, la combinaison des vagues et d'un courant soutenu constitue probablement le mécanisme engendrant ces formes de litage.

[Traduit par le joumal]

\section{INTRODUCTION}

The Grand Banks of Newfoundland consist of several banks which form a continental shelf extending out some $350 \mathrm{~km}$ into the North Atlantic ocean (Fig. 1). At the outer margin of the largest of the banks, Grand Bank, sidescan sonar surveys and bottom photography have revealed sediment in movement (Fader and King, 1981; Barrie et al., 1984). Their evidence has suggested that unidirectional flows in excess of $0.50 \mathrm{~m} / \mathrm{s}$ occur occasionally, with sediment transport towards the south and parallel to the isobaths (Barrie et al., 1984).

Transport at the shelf-break of Grand Bank has been interpreted generally on the basis of indirect evidence, such as seabed morphology and lithofacies. Storm-induced currents are considered to be the most influential mechanism for transporting sediment in this environment (Karl et al., 1983). For example, such currents were found to be responsible for transporting sediment at the sheif-slope boundary off Nova Scotia (Fig. 1), to the southwest of the Grand Banks (Hill and Bowen, 1983). In this area, significant transport occurs along the slope.

Since 1979, wave data and current meter observations (Fig. 2) have been obtained for the norheastern margin of Grand Bank through: Mobil Oil Canada Limited, operators for the Hibernia hydrocarbon discovery; the Geological Survey of Canada; and the Centre for Cold Ocean Resources Engineering (C-CORE). On the basis of these data sets, we are able to define the frequency and magnitude of the disturbance to the seabed by waves and currents, by defining the entrainment and depositional conditions under unidirectional and oscillatory flow. The results are then compared to the distribution of bedforms over the northeastern region of Grand Bank.

*Present address: Geological Survey of Canada, Pacific Geoscience Centre, P.O. Box 6000, Sidney, British Columbia V8L 4B2, Canada 


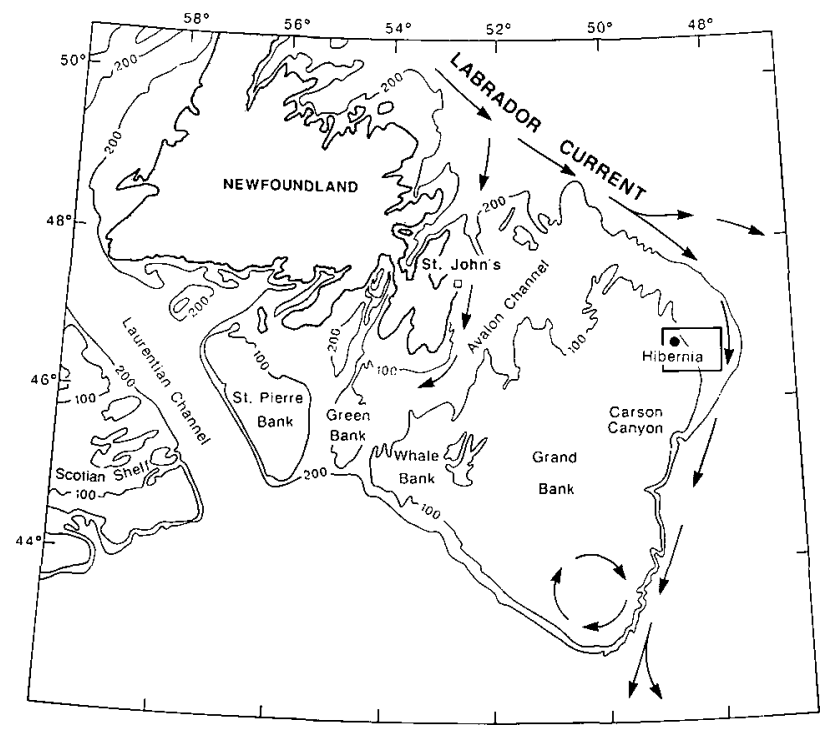

Fig. 1. Water circulation on the Newfoundland continental shelf (after Petrie and Anderson, 1983). Bathymetry is shown in metres.

\section{DATA COLLECTION}

During a cruise of the MV Polaris $\underline{V}$ in June, 1980, some 152 Van Veen grab samples were collected in a $4 \mathrm{~km}$ grid over the study area (Amos and Barrie, 1980). Standard grain size analysis by seiving was carried out on the samples at $1 / 2$ phi intervals.

Between 1980 and 1985 , measurements of current speed were collected at 12 locations on the northeastern margin of Grand Bank (Fig. 2). From April 1980 to January 1981, up to 5 near-bed current meters were placed at 10 different locations (by MacLaren Plansearch Limited) (Fig. 2). Between November 1984 and January 1985, and from August to November 1985, bottom current measurements were collected at two sites centred in the Hibernia oil field (Fig. 2). For all current measurements, Aanderaa (RCM-4) self-recording current meters were mounted on a frame at $0.5 \mathrm{~m}$ off the seabed with a sampling interval of $10 \mathrm{~s}$; these recorded current speed, current direction, temperature and conductivity. Wave data, collected with wave rider buoys, were obtained by the Marine Environmental Data Service (MEDS) from 6 hydrocarbon drilling locations within the same area (Fig. 2). The data represent the period from November 1979 to February 1982.

Manned submersible observations, together with $100 \mathrm{kHz}$ sidescan sonar surveys, were completed over the Hibernia area in October 1984 using the SDL-1 submersible and tender vessel HMCS Cormorant (Barrie and Collins, 1985). During the submersible dives, $15 \mathrm{~kg}$ of an inert tracer sand (europium-doped corderite glass) were emplaced on the seafloor at the site of the Hibernia P-15 well (Fig. 2). The tracer had a mean grain size of $0.32 \mathrm{~mm}$ with a distribution typical of sand found in the area. The tracer acted as a visual indication of sediment movement due the iridescent nature of the colorless glass under the lights of the submersible.

\section{REGIONAL SETTING}

\section{Geological}

The surficial sediments over the area consist primarily of fine sands to gravels, which form part of a thin Quaternary sequence of sediment facies at the shelf edge (Barrie et al., 1984). Sands below $110 \mathrm{~m}$ water depth are moderately-well-sorted and have a mean grain-size of $0.23 \mathrm{~mm}$. Few gravels are found. Above $110 \mathrm{~m}$ water depth sands are moderately-sorted with a mean grain-size of $0.35 \mathrm{~mm}$ and interspersed with gravels. The facies range from a continuous sheet of fine sand $(110-130 \mathrm{~m}$ water depth), through lag gravel with sand ribbons and arcuate sand waves and megaripples normal to the axes of the sand ribbons (100-110 m water depth). A thin contour-parallel sand body follows a terrace slope located between 85 and $100 \mathrm{~m}$ water depth. In water depths less than $85 \mathrm{~m}$, coincident with the flattened surface of Grand Bank, sand ridges up to $5 \mathrm{~m}$ in height alternate with troughs of lag gravels. On the sand ridge flanks and crest megaripples and arcuate sand waves, with megaripples on their stoss sides, are common (Barrie et al., 1984). Some megaripples are well-developed but primarily they are poorly defined and degraded.

\section{Physical Oceanographical}

The Labrador Current, with mean surface speeds of about $0.2 \mathrm{~m} / \mathrm{s}$ controls the general pattern of water circulation over the Newfoundland shelf (Greenberg and Petrie, 1988; Petrie and Anderson, 1983). The southerly flowing Labrador Current branches into distinct streams (Fig. 1) over the Newfoundland shelf and the Grand Banks (Matthews, 1914; Smith et al., 1937). The (Hibernia) research area lies just to the west of the central branch, which follows the eastern edge of the continental shelf (Fig. 1).

Tidal range within this area is small, resulting in low tidal current velocities (i.e., $<0.1 \mathrm{~m} / \mathrm{s}$ at $80 \mathrm{~m}$ watcr depth). Conversely, wind-driven currents are considered to be significant controls on water movement in fall and winter, although they cannot presently be modelled duc to the lack of continuous observations (Petrie, 1982). Analyses of wind driven currents acting on the seafloor is presently underway (C. L. Amos, personal communication).

The wave climate for the Canadian Atlantic continental shelf, including the Hibernia area, was examined by Ncu (1976; 1982). Monthly significant wave height $\left[\mathrm{H}_{\text {sig }}\right.$, the mean height of the highest one-third waves in a record (Wiegel, 1964; Neu, 1976)] and wave period [ $\mathrm{T}_{\text {sig }}$, approximately 0.9 of the peak period (Goda, 1978)] are presented in Table 1. Highest $\mathrm{H}_{\text {sig }}$ for the Hibernia area, on one, ten and 100 year return periods are 9.0 $\mathrm{m}, 12.3 \mathrm{~m}$ and $15.6 \mathrm{~m}$, respectively, corrcsponding to maximum heights of $16.2 \mathrm{~m}, 22.2 \mathrm{~m}$ and $28.1 \mathrm{~m}$ ( Neu, 1982). Wave heights exceed $1.5 \mathrm{~m}$ over 60 to $80 \%$ of the time and pcriods, based upon 


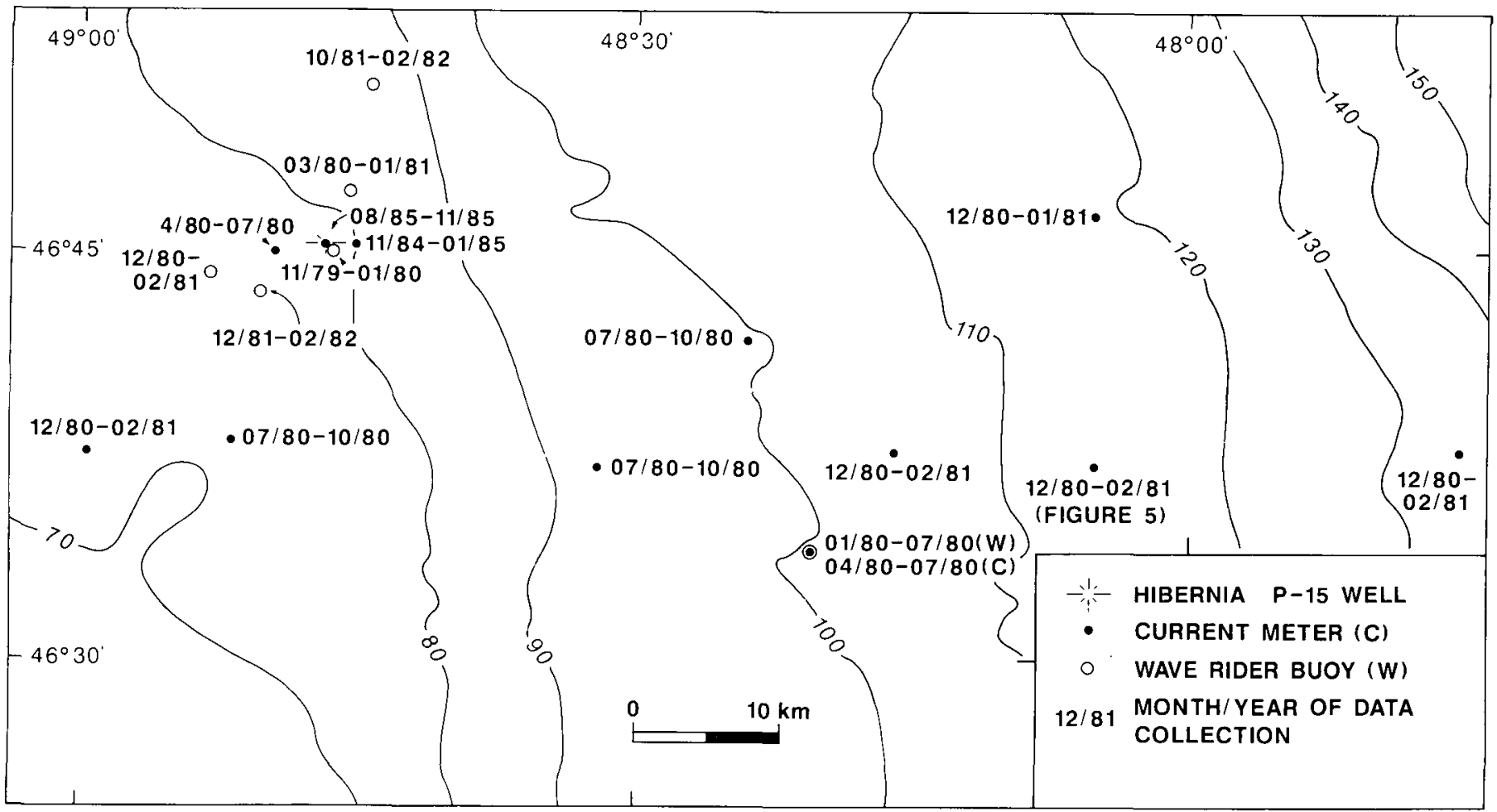

Fig. 2. Location of bottom mounted current meters and wave rider buoys, from which wave and current data have been abstracted (dates denote periods of data collection). Bathymetry is shown in metres.

Table 1. Mean monthly significant wave height $\left(\mathrm{H}_{\text {sig }}\right)$ and significant wave period $\left(\mathrm{T}_{\text {sig }}\right)$ and the dominant direction of wave approach, on the northeastern margin of the Grand Banks. Wave heights and period have been averaged on a yearly basis from data collected between November 1979 and February 1982 (Fig. 2) and wave direction is based on an 11 year record from Neu (1982).

Month $\quad \mathrm{H}_{\text {sig }}(\mathrm{m}) \quad \mathrm{T}_{\text {sig }}(\mathrm{s}) \quad$ Wave Direction
$(>60 \%)$

\begin{tabular}{llrl} 
Jan. & 5.5 & 11.0 & NW \\
Feb. & 5.0 & 11.0 & NW, W \\
March & 5.0 & 11.0 & SW, W \\
April & 4.5 & 10.0 & NW, SW, E \\
May & 3.5 & 10.0 & NE, SW \\
June & 3.0 & 9.0 & NW, SW \\
July & 3.0 & 8.0 & SW, NW \\
Aug. & 3.0 & 9.0 & NW, SW \\
Sept. & 4.0 & 10.0 & NW \\
Oct. & 4.0 & 10.0 & NW \\
Nov. & 5.0 & 11.0 & NW, W, N \\
Dec. & 6.0 & 11.0 & NW, N \\
& & & \\
\hline
\end{tabular}

the largest $3 \%$ of the waves recorded monthly, range between 11 to $14 \mathrm{~s}$ (Neu, 1982).

Between September and March, waves approach primarily from the northwest and west (>50\%) (Table 1). From April to August, wave approach is predominantly from the southwest and northwest. Over a typical year, most storms originate from the northwest, with decreasing frequencies from the west, southwest, south, north and east.

\section{RESULTS}

\section{Wave (Oscillatory Current) Analysis}

Using the measured wave periods $\left(\mathrm{T}_{\text {sig }}\right)$ and heights $\left(\mathrm{H}_{\text {sig }}\right)$ from November 1979 to February 1982 (Table 1), linear Airy wave theory was employed to calculate near-bed orbital velocities in $70 \mathrm{~m}$ water depth. The monthly mean values are graphed in Figure 3. The dominance of these orbital velocities generated by storm waves over currents is apparent for the winter months of November to March (Fig. 3).

Sediment threshold under oscillatory flow can be expressed using the critical threshold equation:

$$
\begin{array}{ll}
\frac{\rho\left(U_{m}\right)^{2}}{\left(\rho_{s}-\rho\right) g D} & \quad 0.21\left(d_{o} / D\right)^{1 / 2} \\
& \text { for } D<0.5 \mathrm{~mm},
\end{array}
$$

where $\rho$ is the density of water and $d_{o}$ is the orbital diameter of water motion (Komar and Miller, 1974). With an input of grain diameter (D) and grain density $\left(\rho_{s}\right)$ into this equation, the threshold velocity $\left(\mathrm{U}_{\mathrm{m}}\right)$ for sediment motion is computed as a function of wave period. For a specific water depth the wave height required for the threshold conditions can be computed using linear wave theory (Komar and Miller, 1975).

By including the average mean grain size for the Hibernia 


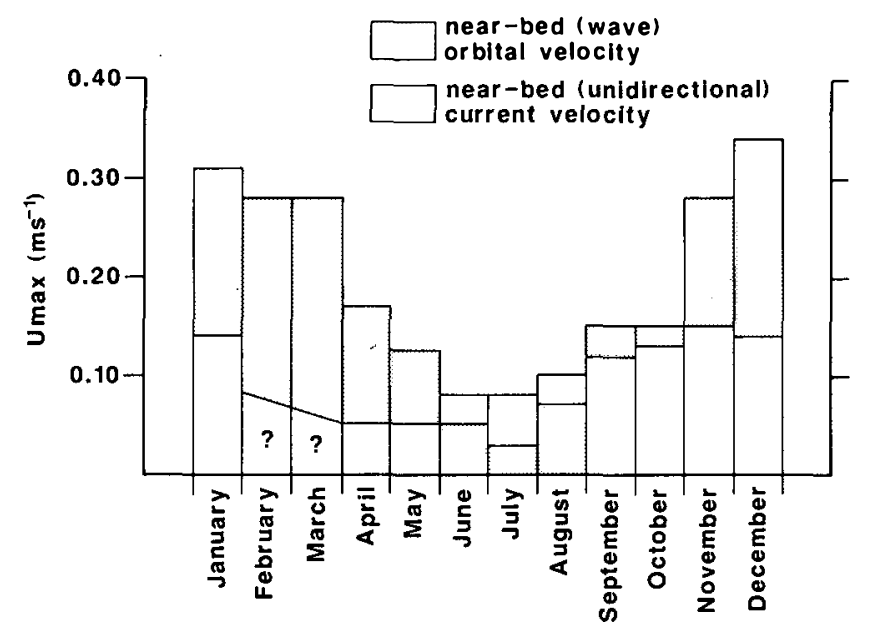

Fig. 3. Mean monthly distribution of maximum bottom oscillatory currents and unidirectional currents at $70 \mathrm{~m}$ water depth for the northeastern Grand Banks.

arca $[0.35 \mathrm{~mm}$ (Barrie et al., 1984)], the equation permits the computation of conditions of threshold exceedence. Using the available measured wave statistics, the percentage frequency of conditions satisfying the threshold criteria can be compared as a function of water depth. Figure 4 shows the results on a monthly basis, for the water depth range of the study area. Between November and March, sediment movement under waves is exceeded over $30 \%$ of the time at $70 \mathrm{~m}$ water depth. Between June and August no appreciable movement of bottom sediments occurs, so that no curves are drawn in Figure 4 for these months.

\section{Regional (Unidirectional) Current Analysis}

Mid-depth currents on the northeastern margin of the Grand Banks have a mean maximum speed of around $0.2 \mathrm{~m} / \mathrm{s}$, with maximum currents reaching $0.95 \mathrm{~m} / \mathrm{s}$ (Petrie, 1982). Currents $0.5 \mathrm{~m}$ above the seabed, during a 10 month period in 1980 and 1981 , had a mean maximum speed of approximately $0.10 \mathrm{~m} / \mathrm{s}$ (Fig. 3). Maximum near-bed currents, including the tidal component, reached $0.45 \mathrm{~m} / \mathrm{s}$ (Petrie, 1982); however, such levels were reached less than $1 \%$ of the recording time.

The currents flow predominantly from northwest to southcast, based upon geostrophic flow computations (Petrie and Anderson, 1983) and near-bed current observations from 1980 to 1985. However, there is a large degree of variability in flow direction, with time scale varying from days to weeks. Although current meters in water depths shallower than $100 \mathrm{~m}$ in the western portion of the study area (Fig. 2) recorded a net northerly flow from June to November in 1981 and August to November in 1985 , those in deeper waters $(>100 \mathrm{~m}$ ) to the east and closer to the central branch of the Labrador Current showed a consistent southerly flow direction with higher velocities than those further inshore. The flow was usually to the south-southeast at time of higher velocity, particularly during the winter months (Fig. 3). A progressive vector diagram from December 1980 to February 1981 , recorded at a current meter station in $116 \mathrm{~m}$ water depth (Fig. 2), illustrates the net south-southeasterly residual current (Fig. 5). This averaged $3.5 \mathrm{~km} /$ day or $0.04 \mathrm{~m} / \mathrm{s}$ at this station.

The near-bottom currents from the study region are above

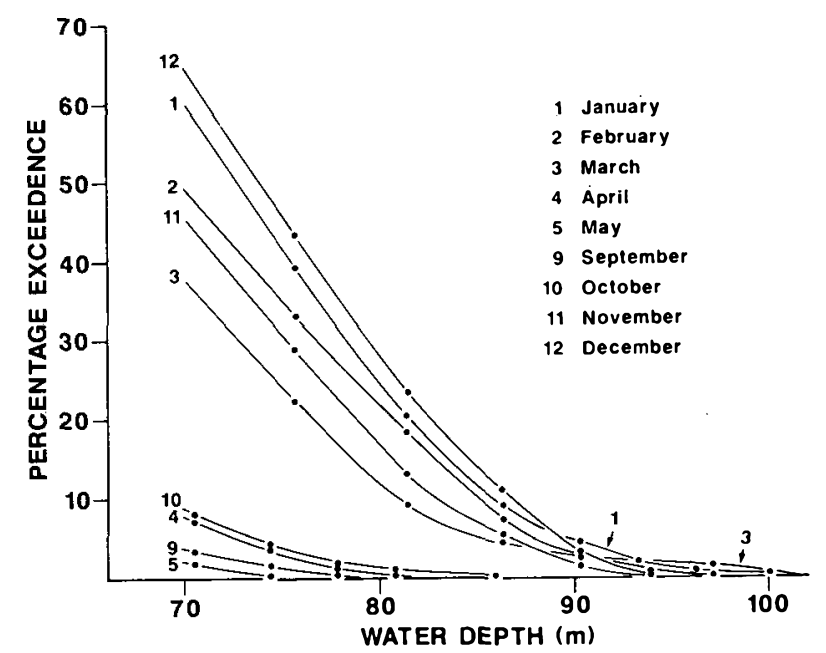

Fig. 4. Sediment transport threshold exceedence curves for a mean grain size $(0.35 \mathrm{~mm})$ over the Hibernia area, under oscillatory motion alone.

threshold for sediment transport for only $2 \%$ of the time, using the non-cohesive sediment threshold curves of the modified Shields graph (Miller et al., 1977). The brief periods of exceedence occur during the winter months with the flow to the south-southeast. In the absence of data from February and March, this analysis is somewhat incomplete: nonetheless bedload transport attributable to unidirectional flows alone is very infrequent.

\section{Combined (Oscillatory and Unidirectional) Flow}

On the basis of the above analysis, transport on the northcastern Grand Banks results from the combincd action of waves and the residual current flow. In a wavc-dominatcd environment mean shear stress on the seabed is enhanced comparcd with the slowly moving current component. Mean stresses within the wave orbital boundary layer tend to be in the direction of wave propagation, rather than aligned with that of the current, unless the oscillatory flow is perpendicular to the current (Grant and Madsen, 1979, 1982). The application of bedload transport formulae to the marine environment, therefore, is complicated by the presence of combined flow. Consequently, computations of bedload transport will not be addressed here due to the lack of concurrently collected data.

\section{Submersible Observations}

Oscillatory motion at the seabcd of the Hibcrnia arca is one of the primary processes that places sediment into suspension. Sand sized material is suspended primarily by bursts and swceps of turbulence related to peak wave strcsscs (Clarke et al., 1982) and vortex shedding from ubiquitous ripples (Davics, 1983). Evaluation of suspended sediment transport rates requircs a knowledge of the vertical distribution of suspended scdiment concentrations, or eddy diffusivity, logether with the relevant velocity profile data (Smith, 1977). Although such information on boundary layer flows or sediment concentrations is not available for the Grand Banks, some uscful submersible observations have been made.

The flank of a sand ridge, near the Hibcrnia P-15 well and in 


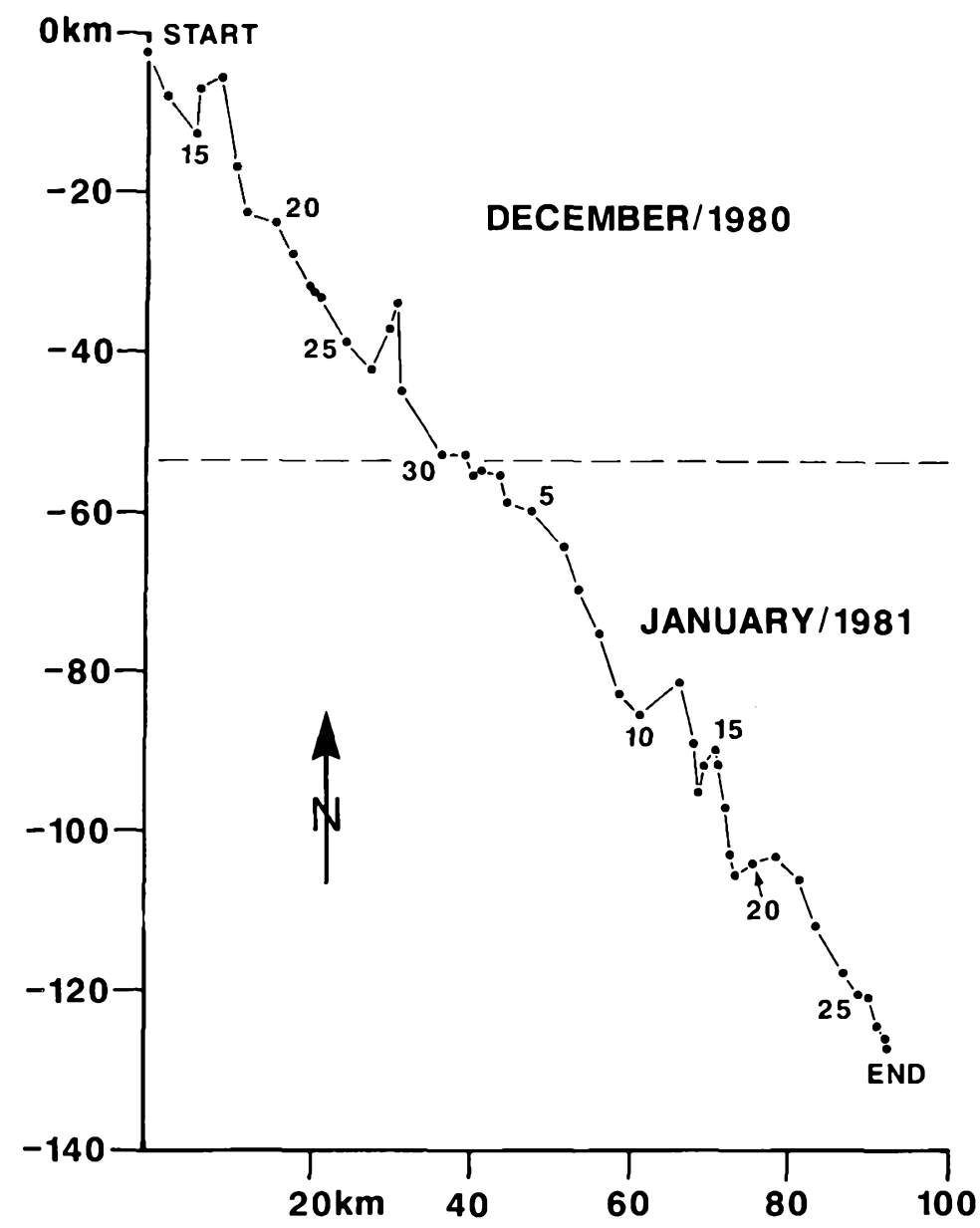

Fig. 5. Progressive vector diagram of current data collected at $116 \mathrm{~m}$ water depth from December 15,1980 to January 29, 1981 (compiled by McLaren Plansearch Limited). Location of data point is shown in Figure 2.

a water depth of $78 \mathrm{~m}$ (Fig. 2), was selected for repeated observations. The seabed bedforms at the observation site consisted of megaripples (10-15 $\mathrm{m}$ wavelength) overlying a thin pebble armouring (Fig. 6). The megaripples were oriented with an east to west crestline, inferring movement in a southerly or northerly direction. Small symmetrical ripples with wavelengths of $20 \mathrm{~cm}$ and amplitudes of 4 to $6 \mathrm{~cm}$ were also observed in sandy areas; their crestline direction ran from northeast to southwest.

The $15 \mathrm{~kg}$ of europium-doped corderite glass and $100 \mathrm{kHz}$ transponder were placed on the seafloor during the first dive (Fig. 7). On a repeat visit, 5 days later, there was little apparent change in the overall sediment distribution, except that a small portion of the colorless tracer sand placed on the seabed had been moved or mixed into the surrounding sediment. When a third dive was made 13 days later, there was a $3.0 \mathrm{~m}$ high surface swell running from the south, with a period of $13 \mathrm{~s}$. In water depths from $71 \mathrm{~m}$ to the bottom $(78 \mathrm{~m})$ visibility from the submersible was less than $1 \mathrm{~m}$ due to high concentrations of suspended sediment (sand); this compares with normal visibility, under quiescent conditions, of $30 \mathrm{~m}$. The colorless tracer sand (Fig. 7) had been completely removed or mixed into the surrounding sediments. Turbulence, resulting from wave-induced currents, prevented safe control of the submersible at the bottom.

These field observations of movement reinforce the quantitative assessment of wave influence, described previously, in that waves clearly control sediment movement in this region.

\section{DISCUSSION}

The results suggest that the net sediment transport directions and those inferred from observations of sand waves on the seabed were towards the south-southeast $\left(150^{\circ}-190^{\circ}\right)$. This direction coincides with the dominant direction of storm waves and with the main flow direction of the Labrador Current. Sediment transport exceedence curves for waves only (Fig. 4) show that sediment movement takes place only in watcr depths of less than $110 \mathrm{~m}$.

Based upon their distribution and character, the migration of arcuate sand waves is also from north to south or northwest to southeast (Barrie et al., 1984). Symmetrical gravel ripples of similar orientation and with wavclengths of up $103 \mathrm{~m}$ and heights of 0.5 to $0.7 \mathrm{~m}$ were observed during submersible observations and on the sidescan sonar records; thesc occur in patches and as distinctive linear bands or ribbons. Similar features found elsewhere have been defined (Forbcs and Boyd, 1987) as being wave-formed ripples. The wave conditions required to form such ripples occur only during the most scvere winter storms. Smaller ripples also show a preferred oricntation indicating movement towards the south-southeast, along the shclf cdgc.

Barrie et al. (1984) have suggested that the $110 \mathrm{~m}$ isobath is the boundary between the extensive bedforms of the shallow waters and the continuous sand facies of the decper waters. This earlier interpretation is in agrecment with the present transport 


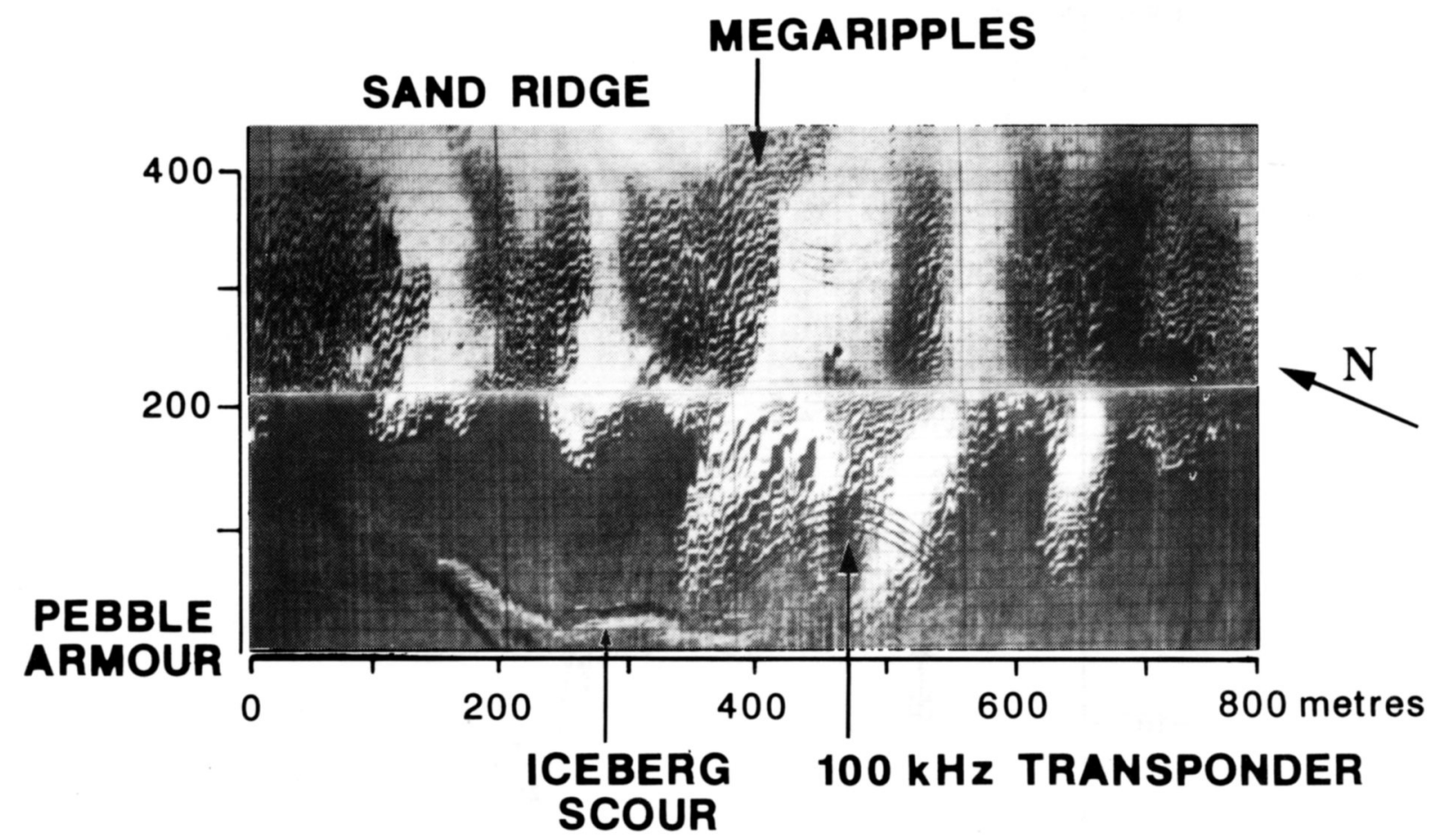

Fig. 6. Sidescan sonogram of the corderite tracer sand site (apex of the four lower parabolas from a $100 \mathrm{kHz}$ pinger) adjacent to the Hibernia $\mathrm{P}-15$ well (Fig. 2). Notice the numerous megaripples (10-15 $\mathrm{m}$ wavelength) on the flank of a sand ridge and the iceberg scour within the gravel lag (trough) on the lower portion of the figure.

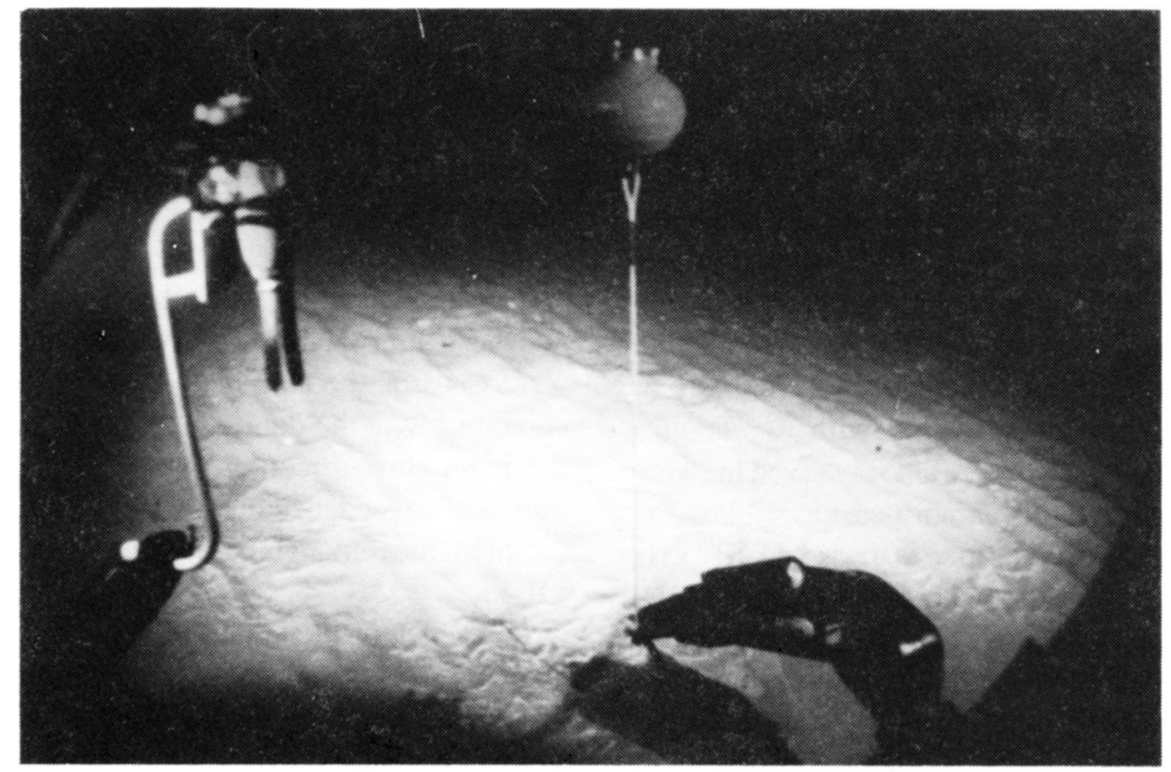

Fig. 7. Distribution of the corderite tracer sand (light colored) deployed from the SDL-1 submersible in October 1984, adjacent to the Hibermia P15 well (Fig. 2). Small (20 cm wavelength) symmetrical bifurcating ripples completely cover the site (Fig. 6 ). In the picture, a $100 \mathrm{kHz}$ Datasonics transponder (source of parabolic pattem in Fig. 6) is being positioned at the edge of the tracer sand. The scale is distorted due to the vicwing dome of the submersible (the buoy line is $1 \mathrm{~m}$ high).

predictions. Unidirectional and oscillatory currents necessary to generate bedforms in water depths less than $110 \mathrm{~m}$ occur very infrequently if they act in isolation. Strong oscillatory flows and wcak currents, which are often in the same direction at Hibernia, rcsult in the observed sedimentary bedforms.

\section{CONCLUSIONS}

The continental shelf of the northeastern Grand Banks of Newfoundland is dominated by wave action. Sediment transport iscontrolled by winter wave conditions, as demonstrated visually 
(from submersible observations) and on the basis of computations of near-bed oscillatory currents. Sediment transport is in a south-southeasterly direction, parallel to the shelf-break. Sand is transported primarily during the winter months in water depths less than $110 \mathrm{~m}$; the $110 \mathrm{~m}$ isobath is considered to represent the wave base.

\section{ACKNOWLEDGEMENTS}

Appreciation is expressed warmly to C.F.M. Lewis, C.L. Amos, D.L. Forbes, B. Petrie and P.D. Komar for their useful suggestions and improvements to this manuscript. Submersible operations were made possible by the Department of National Defence and the Geological Survey of Canada. Assistance in the submersible program was provided by W.T. Collins and in computer programming by G. Stapleton and A. Simms. The work was supported by an Office of Energy Research and Development (OERD) funding contract to the senior author through the Department of Energy, Mines and Resources (Canada).

AMOS, C.L. and BARRIE, J.V. 1980. Hibemia and Ben Nevis seabed study - Polaris V cruise report, June 1980. C-CORE Data Report $80-17,40 \mathrm{p}$.

BARRIE, J.V. and COLLINS, W.T. 1985. Preliminary results of investigations into seabed stability in the Hibernia region of the Grand Banks during operations of HMCS Cormorant and SDL-1 submersible. Geological Survey of Canada, Open File Report, 35 p.

BARRIE, J.V., LEWIS, C.F.M., FADER, G.B., and KING, L.H. 1984. Seabed processes on the northeastern Grand Banks; modem reworking of relict sediments. Marine Geology, 57, pp. 209-227.

CLARKE, T.L., SWIFT, D.J.P., and YOUNG, R.A. 1982. A stochastic modelling approach to fine sediment budget of the New York Bight. Joumal of Gcophysical Research, 88, pp. 9653-9660.

DAVIES, A.G. 1983. Wave interactions with rippled sand beds. In Physical Oceanography of Coastal and Shelf Seas. Edited by B. Johns. Elsevier Science Publishing Company, Amsterdam, pp. 165.

FADER, G.B. and KING, L.H. 1981. A reconnaissance study of the surficial geology of the Grand Banks of Newfoundland. Current Research, Part A, Geological Survey of Canada, Paper 81-1A, pp. 45-81.

FORBES, D.L. and BOYD, R. 1987. Gravel ripples on the inner Scotian shelf. Journal of Sedimentary Petrology, 57, pp. 46-54.

GODA, Y. 1978. The observed joint distribution of pcriods and heights of sea waves. In Proceedings of the 16th Coastal Engincering Conference. Hamburg, West Germany, ASCE, 1, pp. 227-246.

GRANT, W.D. and MADSEN, O.S. 1979. Combined wave and current interaction with a rough bottom. Journal of Geophysical Research, 84, pp. 1797-1808.

1982. Moveable bed roughness in unsteady oscillatory flow. Journal of Geophysical Research, 87, pp. 469-481.

GREENWOOD, D.A. and PETRIE, B.D. 1988. The mean barotropic circulation on the Newfoundland shelf and slope. Journal of Geophysical Research, 93, pp. 15,541-15,550.

HILL, P.R. and BOWEN, A.J. 1983. Modern sediment dynamics at the shelf-slope boundary off Nova Scotia. In The Shelfbreak: Critical Interface on Continental Margins. Edited by D.J. Stanley and G.T. Moore. Society of Economic Paleontologists and Mincralogists, Special Publications, 33, pp. 265-276.

KARL, H.A., CARSON, P.R., and CACCHIONE, D.A. 1983. Factors that influence sediment transport at the shelf break. In The Shelfbreak: Critical Interface on Continental Margins. Edited by D.J.Stanley and G.T. Moore. Society of Economic Paleontologists and Mineralogists, Special Publications, 33, pp. 219-231.

KOMAR, P.D. and MILLER, M.C. 1974. Sediment threshold under oscillatory waves. In Proceedings of the 14th Coastal Engineering Conference. Copenhagen, Denmark, ASCE, 1, pp. 756-775.

. 1975. On the comparison between the threshold of sediment motion under waves and unidirectional currents with a discussion of the practical evaluation of the threshold. Journal of Sedimentary Petrology, 45, pp. 362-367.

MATTHEWS, D.J. 1914. Report on the work carried out by the $\underline{S S}$ Scotia, 1913. Ice observation, meteorology and oceanography in the North Atlantic Ocean. Darling and Son Publishers, London.

MILLER, M.C., McCAVE, I.N., and KOMAR, P.D. 1977. Threshold of sediment motion under unidirectional currents. Scdimentology, 24, pp. 507-527.

NEU, H.J.A. 1976. Wave climate of the North Atlantic, 1970. Atlantic Oceanographic Laboratory, Bedford Institute of Oceanography, Report Series BI-R-76-10, 37 p.

1982. 11-year deep-water wave climate of Canadian Atlantic waters. Canadian Technical Report of Hydrography and Ocean Sciences, 13, $41 \mathrm{p}$.

PETRIE, B. 1982. Aspects of the circulation on the Newfoundland continental shelf. Canadian Report of Hydrography and Ocean Sciences, $11,78 \mathrm{p}$.

PETRIE, B. and ANDERSON, C. 1983. Circulation on the Newfoundland continental shelf. Atmospherc-Ocean, 21, pp. 207-226.

SMITH, J.D. 1977. Modeling of sediment transport on continental shelves. In The Sea. Volume 6. Edited by E.D. Goldberg, I.N. McCave, J.J. O'Brien, and J.H. Stcelc. Wiley-Interscience, New York, pp. 539-577.

SMITH, E.H., SOULE, F.M., and MOSBY, D. 1937. The Marion and General Greene expeditions to Davis Strait and Labrador Sca. Bulletin of the United States Coast Guard, 13, 259 p.

WIEGEL, R.L. 1964. Oceanographical Engineering. Prentice-Hall, Englewood Cliffs, New Jersey, 532 p. 